\title{
PEMANFAATAN GAPHICS DESIGNER SOFTWARE UNTUK MENINGKATKAN KREATIFITAS PROMOSI PRODUK PARA PENGUSAHA UMKM DI KOTA TEGAL
}

\author{
Muhammad Fikri Hidayatullah'), Muhammad Yoka Fathoni'), \\ Dairoh $^{3)}$, Yustia Hapsari ${ }^{4}$ ) \\ ${ }^{123}$ Program Studi D IV Teknik Informatika Politeknik Harapan Bersama Tegal \\ Jl. Mataram No. 9 Pesurungan Lor, Kota Tegal, Jawa Tengah 52147 \\ ${ }^{4}$ Program Studi S1 SistemInformasi STMIK YMI Tegal \\ Jl. Pendidikan No.1, PesurunganLor, Margadana, Kota Tegal, Jawa Tengah 52122
}

\begin{abstract}
Abstrak
Usaha Mikro Kecil dan Menengah (UMKM) memiliki peran yang cukup tinggi dalam perekonomian di Indonesia. UMKM mampu menyediakan lapangan pekerjaan dan menghasilkan output yang berguna bagi masyarakat. Akan tetapi dalam perkembangannya UMKM masih menemui berbagai kendala untuk memajukan usahanya. Salah satu kendala tersebut terkait pemasaran produk usahanya. Langkah solutif yang dapat ditempuh untuk meningkatkan promosi produknya adalah dengan membuat desain promosi yang menarik. Dari hasil analisis Tim Pengabdian Kepada Masyarakat Program Studi D IV Teknik Informatika Politeknik Harapan Bersama Tegal bahwa para pengusaha UMKM dapat diberikan pelatihan untuk mampu membuat sendiri segala bentuk promosi usahanya yang meliputi logo dan pamflet. Oleh karena itu dipilihlah graphicsdesigner software yang sangat mudah dan cepat dalam pengoperasiannya yaitu AAA Logo dan Canva. Pelatihan ini berlangsung selama dua hari pada tanggal 23-24 Desember 2017. Pelaksanaan pelatihan dalam rangka Pengabdian Kepada Masyarakatberjalan dengan sangat baik dan para peserta mampu membuat logo dan brosur produk usahanya secara mandiri.
\end{abstract}

Kata kunci : UMKM, desain, logo, Tegal

\begin{abstract}
Micro Small and Medium Enterprises (MSMEs) have a fairly high role in the economy in Indonesia. MSMEs are able to provide jobs and generate useful output for the community. However, in its development, MSMEs still encounter various obstacles to advance their business. One such obstacle related to the marketing of its business products. Solutive steps that can be taken to improve the promotion of products is to create an attractive promotional design. Based on the analysis of Community Service Team Study Program D IV Informatics Engineering Polytechnic of Harapan Bersama Tegal that UMKM entrepreneurs can be given training to be able to make their own all forms of business promotion which includes logos and pamphlets. Therefore selected graphics designer software that is very easy and fast in operation that is AAA Logo and Canva. The training was held for two days on 23-24 December 2017. The training implementation in the framework of Community Service was running very well and the participants were able to create their own logo and brochures of their products independently.
\end{abstract}

Keywords : MSMEs, design, logo, Tegal

Correspondence author: Muhammad Fikri Hidayatullah fikri@poltektegal.ac.id Tegal, Indonesia

his work is licensed under a $C C-B Y-N C$ 


\section{PENDAHULUAN}

Usaha Mikro Kecil dan Menengah (UMKM) memiliki peran yang cukup besar bagi perkembangan perekonomian bangsa Indonesia. Salah satu peran praktis UMKM adalah mampu menyerap tenaga kerja yang sangat besar dan memberikan income pajak penghasilan bagi pemerintah (Herman, Hidayah, \& Raharja, 2013). UMKM juga mampu dijadikan sebagai embrio untuk melangkah dari sebuah usaha kecil menjadi perusahaan besar. Data dari Dinas Koperasi dan UMKM tahun 2012 menunjukkan bahwa peranan UMKM dalam geliat perekonomian Indonesia sangat penting. Karena UMKM mampu menyediakan lapangan pekerjaan dan menghasilkan output yang berguna bagi masyarakat (Ananda \& Susilowati, 2017).

Kota Tegal dahulu dikenal sebagai kota bahari yang terkenal dengan hasil lautnya yang melimpah. Seiring perkembangan zaman dan pergeseran waktu terjadi banyak perubahan dalam sektor ekonomi. Banyak penduduknya membuka usaha kecil dan menengah. Jenis usaha tersebut diantaranya pengolahan dan penjualan telor asin, usaha kuliner, penjualan pakaian hingga berbagai variasi usaha online shop. Survei dari Badan Pusat Statistik (BPS) mengindentifikasi bahwa salah satu kelemahan dan permasalahan yang dihadapi UMKM adalah terkait kesulitan dalam pemasaran (Hadiyati, 2011). Pemasaran suatu produk milik UMKM tentu tidak lepas dari desain promosi maupun kemasan produk yang dipasarkan. Desain yang menarik berpengaruh terhadap minat beli customers(Rosandi \& Sudarwanto, 2014). Oleh karena itu salah satu langkah strategis yang dapat ditempuh para pengusaha UMKM adalah dengan membuat desain promosi produknya semenarik mungkin.

Bagi pengusaha UMKM yang masih dalam tahap merintis dengan modal yang terbatas tentunya agak terhambat apabila harus mengeluarkan dana tambahan untuk segala keperluan biaya desain promosi produknya. Dan hal ini malah bisa mengakibatkan kendala baru bagi perkembangan usahanya. Permasalahan ini dapat diatasi apabila para pengusaha UMKM dapat memiliki kemampuan desain secara mandiri tanpa tergantung sepenuhnya kepada jasa desainer yang membutuhkan biaya cukup besar. Sehingga untuk keperluan desain promosi tidak perlu mengeluarkan dana tambahan lagi.

Salah satu langkah solutif yang dapat ditempuh untuk mengatasi kendala tersebut adalah dengan memberikan pelatihan kepada para pelaku usaha UMKM cara membuat desain promosi produk yang menarik tapi mudah dalam pembuatannya serta tidak memakan waktu belajar terlalu lama. Desain tersebut meliputi desain brosur, pamflet, logo dan keperluan desain promosi lainnya. Untuk itu, Tim Pengabdian Kepada Masyarakat (PKM) Program Studi D IV Politeknik Harapan Bersama Tegal membantu para pengusaha UMKM ini untuk mampu membuat desain promosi produknya secara mandiri melalui pelatihan dengan tema "Pemanfaatan Graphic Designer Software untuk Meningkatkan Kreatifitas Promosi Produk Para Pengusaha UMKM Kota Tegal”.

Pelatihan dalam rangka PKM yang dilaksanakan selama dua hari pada tanggal 2324 Desember 2018 memanfaatkan tools AAA Logo dan Canva. Kedua tools ini sangat praktis dan cepat dalam membuat desain dengan hasil yang cukup memuaskan tanpa perlu keahlian khusus dalam bidang desain grafis.

Untuk menunjang kegiatan pelatihan seputar desain dalam rangka pengabdian kepada masyarakat diperlukan alat dan bahan penunjang. Peralatan tersebut meliputi seperangkat unit PC (Personal Computer) untuk pengoperasian graphic designer software, koneksi internet untuk mengakses laman www.canva.com dan printer untuk 
mencetak hasil desain para peserta. Sedangkan untuk bahan penunjang dibutuhkan kertas HVS dan kertas stiker sebagai media cetak untuk menampilkan hasil desain para peserta.

\section{METODE PELAKSANAAN}

Sebelum kegiatan pengabdian kepada masyarakat dilaksanakan maka dilakukan persiapan-persiapan sebagai berikut:

a. Melakukan observasi dan studi literature tentang permasalahan dan kebutuhan para pengusaha UMKM di Kota Tegal.

b. Setelah diketahui permasalahan dan kebutuhan yang dibutuhkan oleh para pengusaha UMKM di Kota Tegal, maka langkah selanjutnya adalah dengan memberikan solusi praktis tapi efektif.

c. Melakukan studi literature seputar software desain grafis yang mudah penggunaannya.

d. Menyusun materi pelatihan dan slide presentasi.

e. Melakukan persiapan perlengkapan serta peralatan sesuai kebutuhan yang diperlukan

f. Menentukan waktu pelaksanaan dan lamanya kegiatan pengabdian bersama-sama tim pelaksana.

Metode kegiatan yang digunakan untuk mencapai tujuan dari kegiatan pengabdian masyarakat ini adalah dengan metode ceramah, praktek dan diskusi. Pertama kali para pemateri menjelaskan materi yang diajarkan. Setelah materi selesai disampaikan peserta langsung mempraktekan materi dengan membuat logo dan desain pamflet. Peserta akan berdikusi dengan para pemateri apabila terdapat beberapa hal yang belum jelas. Mahasiswa yang ikut membantu dalam kegiatan ini bertugas mendampingi para peserta secara intens.

\section{HASIL DAN PEMBAHASAN}

Kegiatan pelatihan "Pemanfaatan Graphic Designer Software untuk Meningkatkan Kreatifitas Promosi Produk Para Pengusaha UMKM Kota Tegal” dilaksanakan di Lab. Komputer 6 Gedung B Politeknik Harapan Bersama Kota Tegal pada tanggal 23-24 Desember 2017. Kegiatan ini diikuti para pengusaha UMKM dari berbagai jenis usaha. Acara pelatihan dimulai pukul 08.30-11.45 WIB. Pemateri kegiatan ini terdiri dari 3 dosen dan dibantu oleh 4 mahasiswa. Para peserta sangat antusias mengikuti program pelatihan ini. 


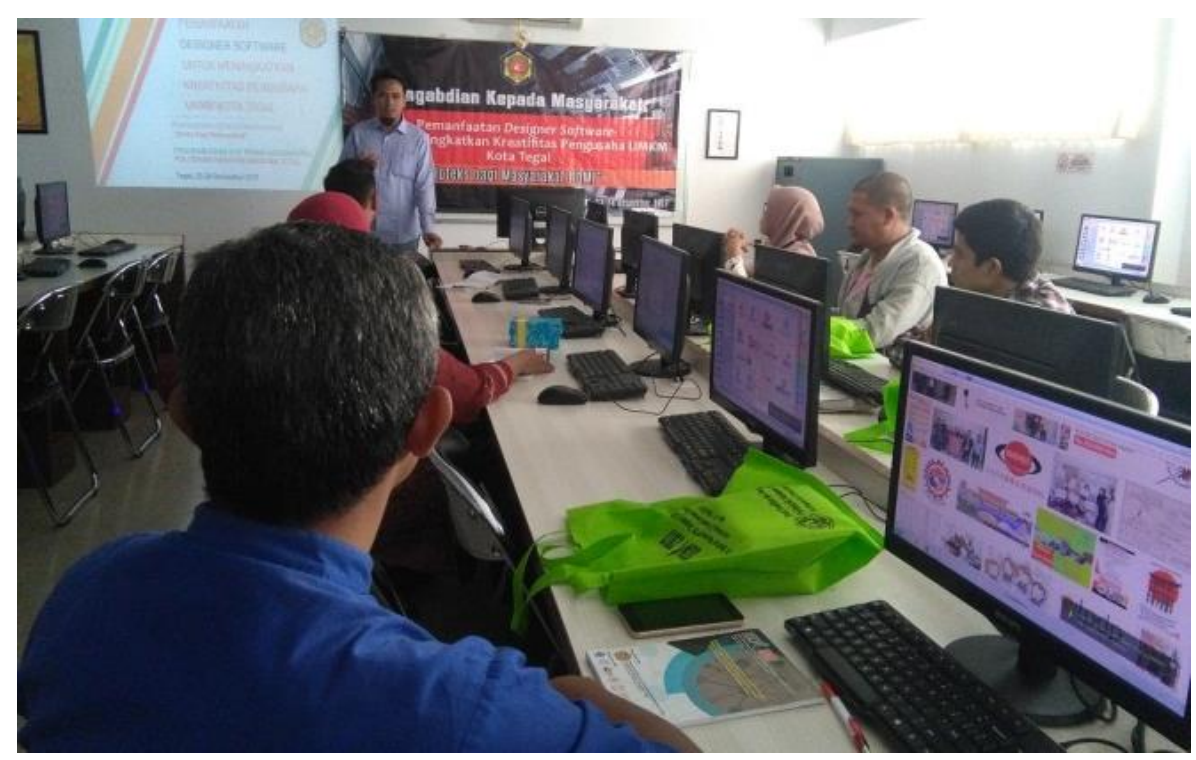

Gambar 1 Pelatihan Hari Pertama

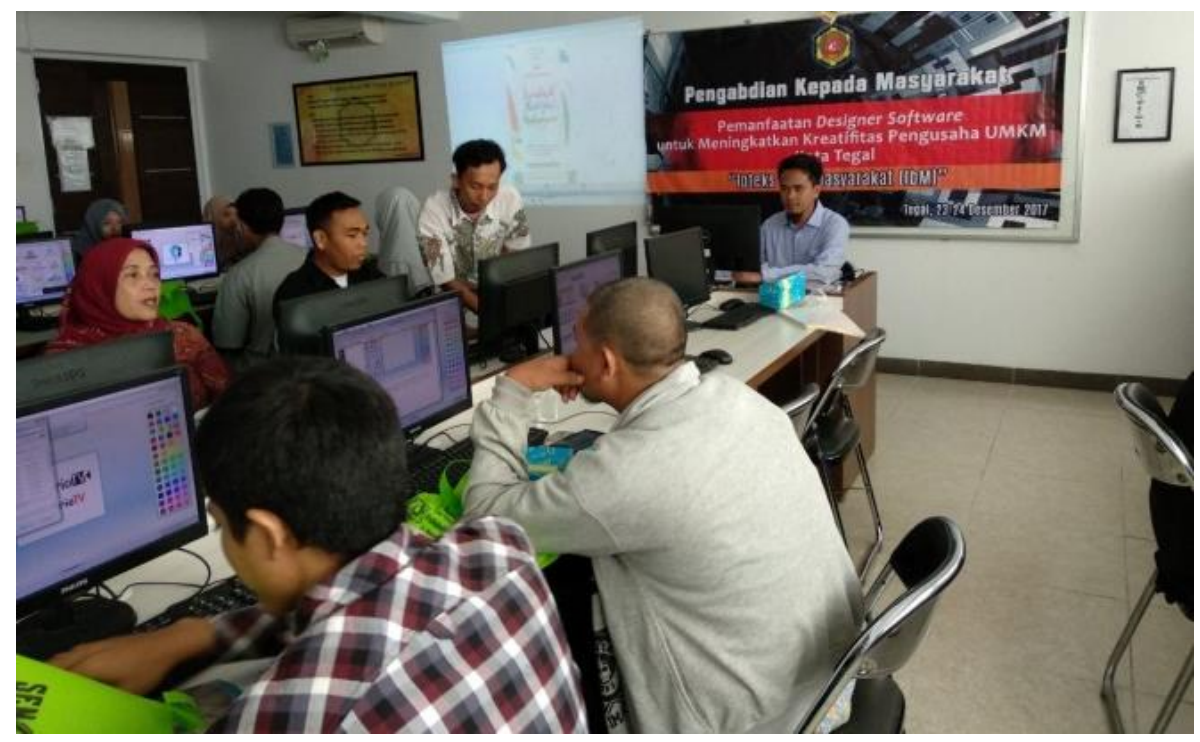

Gambar 2 Pelatihan Hari Kedua

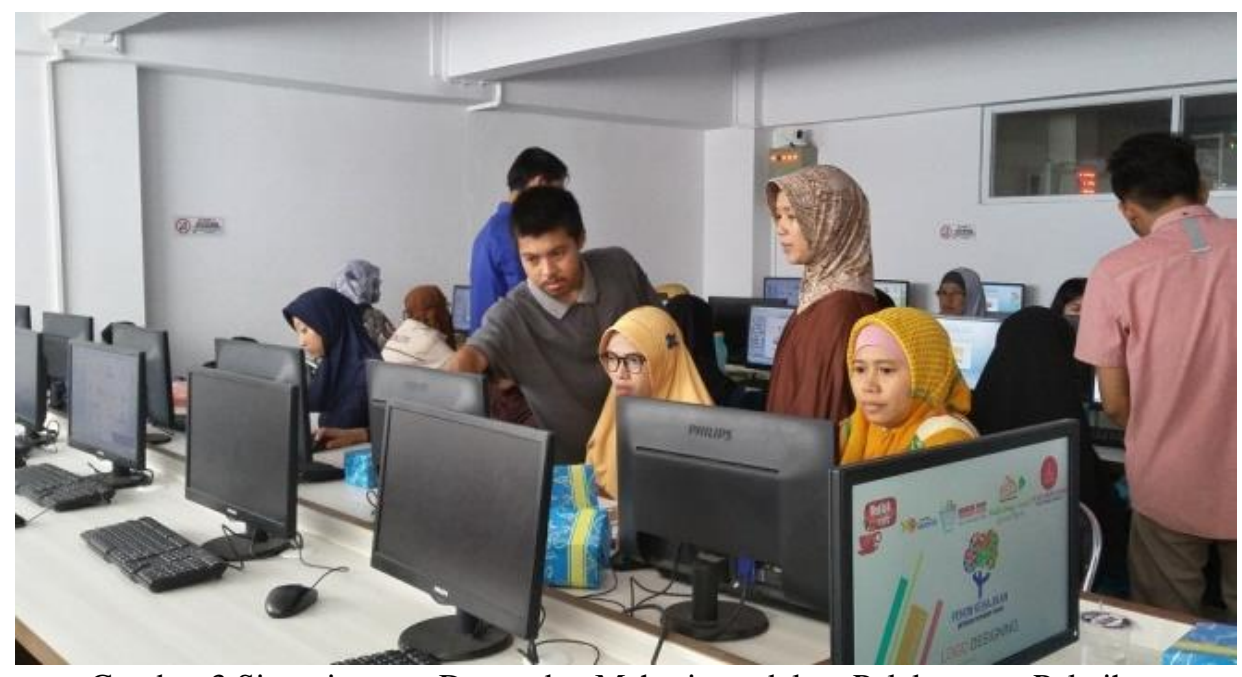

Gambar 3 Sinergi antara Dosen dan Mahasiswa dalam Pelaksanaan Pelatihan 
Para peserta pada hari pertama dan kedua terdiri dari pengusaha UMKM yang berbeda. Dalam satu hari para peserta ditarget untuk dapat menghasilkan minimal satu desain logo usahanya dan pamflet promosi produknya. Desain logo menggunakan tools AAA Logo. Tools ini sangat mudah dan cepat pengoperasiannya. Sedangkan untuk mendesain pamflet promosi produk menggunakan online tools yaitu Canva. Canva merupakan software untuk desain yang cara pengoperasiannya secara online melalui laman www.canva.com. Karena waktu yang terbatas masih banyak peserta yang belum menyelesaikan desain pamflet produk usahanya. Akan tetapi untuk desain pembuatan logo semua peserta mampu membuatnya.

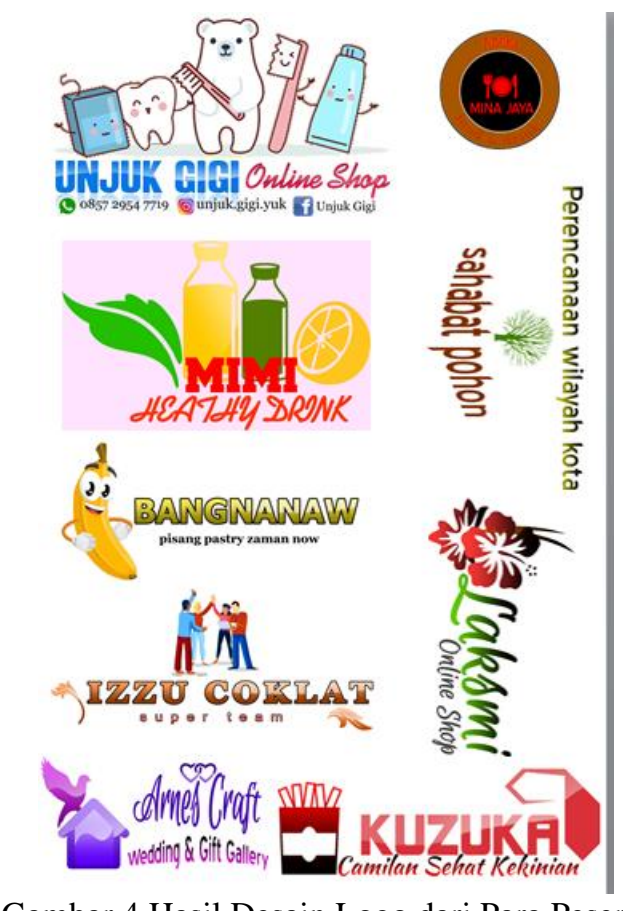

Gambar 4 Hasil Desain Logo dari Para Peserta

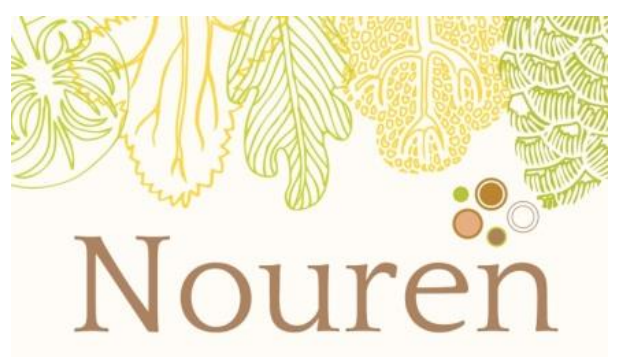

B A T I K G A L E R Y

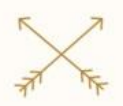

JL. GLATIK 68, RANDUGUNTING, KOTA TEGAL

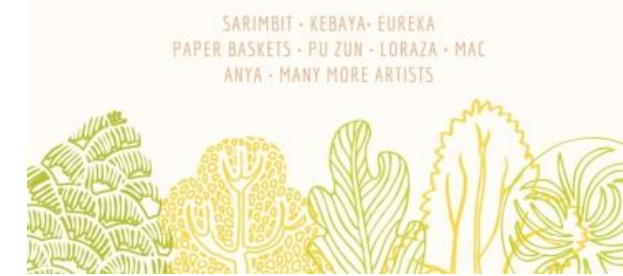

Gambar 5 Desain Pamflet/ Brosur Menggunakan Canva 


\section{SIMPULAN}

Dari kegiatan pengabdian kepada masyarakat ini terdapat berberapa hal yang dapat disimpulkan di antaranya:

1. Pelatihan desain grafis ini mampu membekali para peserta ilmu desain logo dan pamflet secara praktis bagi para pelaku usaha UMKM untuk meningkatkan nilai dan promosi produknya.

2. Melalui kegiatan pelatihan ini para peserta mampu menghasilkan desain logo dan brosur usahanya dengan hasil yang cukup bagus dan berkualitas.

3. Terjalinnya kerjasama antara dunia akademik dengan para praktisi usaha di level menengah

\section{DAFTAR PUSTAKA}

Ananda, A. D., \& Susilowati, D. (2017). Pengembangan Usaha Mikro Kecil dan menengah (UMKM) Berbasis Industri Kreatif di Kota Malang. Jurnal Ilmiah Ekonomi, 10, 120-142.

Hadiyati, E. (2011). Kreativitas dan Inovasi Berpengaruh Terhadap Kewirausahaan Usaha Kecil. Jurnal Manajemen Dan Kewirausahaan, 13(1). https://doi.org/10.9744/jmk.13.1.8-16

Herman, O. :, Hidayah, N., \& Raharja, L. (2013). Peranan Usaha Mikro Kecil Dan Menengah Dalam Pembangunan Ekonomi Indonesia Melalui Pajak (Peraturan Pemerintah No. 46 Tahun 2013). JP Fakultas Ekonomi Dan Bisnis Unsoed, 3(46).

Rosandi, S., \& Sudarwanto, T. (2014). Pengaruh Citra Merek dan Desain Kemasan Terhadap Minat Beli Konsumen pada Produk Susu Ultra. Jurnal Pendidikan Tata Niaga, 2(2), 1-16. 